\title{
Implementing long-term care systems in the Americas: a regional strategy
}

\author{
Pablo Villalobos Dintrans, ${ }^{1}$ Mallika Mathur, ${ }^{2}$ Emmanuel González-Bautista, ${ }^{3}$ Jorge Browne, ${ }^{4}$ Carolina \\ Hommes, ${ }^{5}$ and Enrique Vega ${ }^{5}$
}

Suggested citation Villalobos Dintrans P, Mathur M, González-Bautista E, Browne J, Hommes C, Vega E. Implementing long-term care systems in the Americas: a regional strategy. Rev Panam Salud Publica. 2021;45:e86. https://doi.org/10.26633/RPSP.2021.86

ABSTRACT The Region of the Americas is facing accelerated demographic and epidemiological changes. As these trends will continue in future years, long-term care needs are expected to rise. How can countries respond to these challenges?

We propose that countries in the Region should invest in the implementation of long-term care systems. Considering the heterogeneity in the Region, we propose a strategy based on three components: (i) understanding the problem; (ii) thinking about solutions; and (iii) building support and consensus. Depending on each country's needs and capacities, these three elements suggest short-term and long-term actions and goals, from generating better information on long-term care needs to the implementation of long-term care systems. Longterm care is a relevant issue for the Region today. The task is challenging, but countries need to embrace it and move forward before it is too late.

Keywords $\quad$ Long-term care; health policy; health systems; social security; health planning; Americas.

The Region of the Americas, and particularly Latin America and the Caribbean, is experiencing a rapid process of population aging. Today, the share of people aged 65 years and above in the Region is one of the lowest in the world, but this will change dramatically in the coming years: by 2085, the Region will be the oldest (1). Similarly, countries are experiencing a process of epidemiological transition, a change that is also marked in Latin America and the Caribbean, that exhibits a significant increase in noncommunicable diseases over the last 25 years (2).

These changes will pose enormous challenges to the countries of the Region in terms of social security systems, including pensions and health. One issue typically neglected in this debate is long-term care (LTC). Although LTC is not a phenomenon exclusive to older people or people with noncommunicable diseases, the previously described processes are expected to drive the increase in LTC needs in the future, influencing both their prevalence and severity $(3,4)$. Several countries have embarked

\footnotetext{
1 Universidad de Santiago de Chile, Santiago, Chile $\square$ Pablo Villalobos Dintrans, pvillalobos.d@gmail.com

2 Independent consultant, Washington, D.C., United States of America
}

on activities to address these issues, following international initiatives such as the Sustainable Development Goals and the recently launched Decade of Healthy Aging (5). Consequently, a debate has started recently in the Region (6).

In this context, it is important to stop asking whether the Region is prepared to deal with this scenario and start asking how the Region is coping with the challenges derived from the increase in LTC needs. The aim of this article is to highlight the relevance of taking urgent actions to design and implement comprehensive responses to these challenges, to help structure the debate around LTC in the Region, and to propose initiatives to support countries in generating policies in the area of LTC.

\section{CONCEPTS AND MEASURES: A STARTING POINT}

A first step to expand the discussion of LTC is to agree on the basic concepts and definitions. Following Kingdon's

\footnotetext{
3 Toulouse University Hospital (CHU Toulouse), Toulouse, France

4 Pontificia Universidad Católica de Chile, Santiago, Chile

5 Pan American Health Organization, Washington, D.C., United States of America
} 
agenda-setting model (7), three streams need to align for a topic to make it into the policy agenda: problem (identified as relevant), policy (feasible solutions available), and politics (political will to work on it). When these elements converge, a policy window opens, facilitating action and change.

When looking at LTC, the lack of definitions becomes crucial: first, having common definitions and measures is key to identifying and agreeing on the existence of a problem. Similarly, it is vital to understand its features to design better responses. Finally, policymakers need to understand what the problem is about, and to be familiar with the discussion. In fact, LTC has been used in the literature as an example of a topic that, despite its relevance, has traditionally been ignored in public policies, either because the problem is invisible or because there are no feasible solutions to deal with it $(7,8)$. Moreover, the lack of information and accurate assessments have been identified as barriers for the implementation of LTC systems around the world (9).

This lack of consensus is found when looking for definitions for the concept of LTC (10-12). Despite the differences, the heart of the concept lies in the idea of requiring support from a third party to perform activities of daily living (ADL) (e.g., personal hygiene, dressing, toileting/continence, transferring, and eating). However, the devil is in the details. To move forward in the debate, we identify three key elements embedded in the concept of LTC: (i) triggered by a loss of functional ability; (ii) help from a third person; and (iii) need for an extended period of time (Figure 1).

Using these criteria to identify LTC is useful, since the concept is usually linked to other issues such as physical impairment (and the use of assistive devices vs. human help), socioeconomic vulnerability (and the need for help because of social vulnerability vs. difficulty to carry out ADL), or a temporary loss of functional capacity (and the arrangements to deal with a short-term and well-defined period vs. the issue of providing help for an undetermined and long period of time).

LTC is regularly operationalized through the calculation of dependency. Dependency-traditionally understood as the ratio between the inactive population and the working population-measures a country's ability to produce goods and services and its rate of consumption (13). From an LTC perspective, the term refers to functional dependency; i.e., the point at which functional ability is such that people require help

FIGURE 1. Criteria to identify long-term care needs in the population

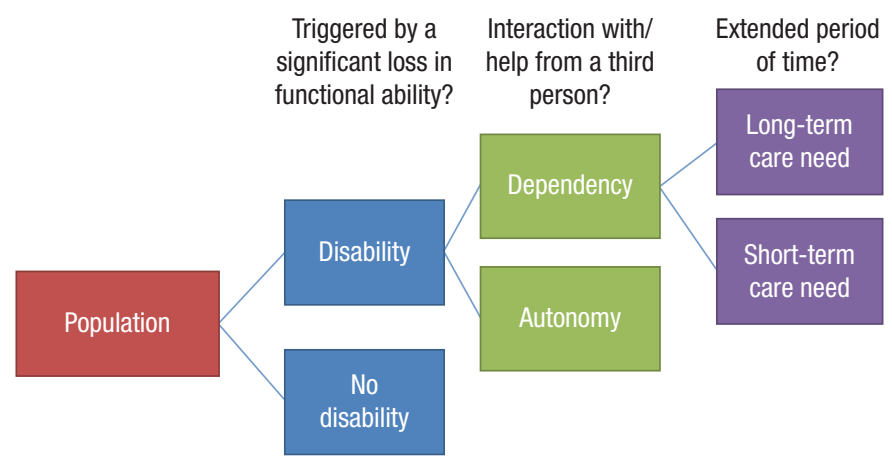

Source: Prepared by the authors to live their lives (11). Unfortunately, the operational definition of functional dependency is unclear, and measurement scarce and heterogeneous. In Latin America and the Caribbean, only six countries have statistics on dependency prevalence $(6,14)$, although countries are attempting to measure these concepts (15-18). Also, definitions used by countries differ, generating comparability issues (19). The problem is even greater when considering that LTC needs to consider not just people with dependency but also their caregivers-usually unpaid family members-who bear the negative mental, physical, and economic consequences of caring $(3,11)$. Regional stakeholders need to play an active role to reach consensus and settle the baseline for further advancing the regional LTC discussion.

\section{LONG-TERM CARE RESPONSES: A PROPOSAL FOR THE COUNTRIES IN THE REGION}

Considering the complexities in defining and measuring LTC, this section proposes a general strategy to generate responses in the countries of the Region. The strategy is based on the design and implementation of LTC systems - understood as national systems put in place to ensure access to LTC services (11) - as an efficient way to deal with the increase in LTC needs in the population (20). However, building an LTC system is complex and takes time, money, and other resources-arguments that are used to resist the implementation of these systems around the world (20-22).

In a context of poor data, constrained resources, and seemingly infeasible solutions, moving forward requires courage and a sound collaborative strategy. The proposed strategy recommends building step-by-step initiatives to move toward the implementation of LTC systems in the Region on three different fronts (7): (i) understanding the problem; (ii) thinking about solutions; and (iii) building support and consensus.

These areas of action work together to promote a better understanding of the challenges of LTC in the Region and take actions to address them. Additionally, it considers the heterogeneity of the Region, allowing for setting of short-term and long-term goals.

\section{Understanding the problem of growing LTC needs (problem stream)}

A first set of actions should be focused on generating information about the situation of LTC in each country, which implies solving definition and measurement issues in the identification of the LTC needs in the population. This is important for estimating the scale and features of the problem but also for defining and selecting beneficiaries for a future LTC system (22). Countries should move in two directions to increase the information, understanding, and awareness on LTC: adopting a national-level definition and generating periodic information on LTC.

Structuring the debate: toward a national definition of LTC needs. One key problem to move forward in the discussion on LTC in the countries is the lack of a definition for the LTC needs: with no agreement on how to measure LTC needs, countries fail to produce information, which, in turn, makes the problem invisible and hinders public policy actions (9).

Considering this, countries should adopt national-level definitions for measuring LTC needs. As this process of selecting 
definitions is key in understanding the challenge of LTC and preparing the path for the implementation of an LTC system, it needs to be performed carefully, making sure that both the theoretical definition and the measurement strategy capture the essence of the problem and how to address it.

The definition of dependency should be broad enough to include all people who require help in performing ADL, regardless of its origin. Here, it is important to consider a traditionally neglected dimension in LTC: mental health. The concept of disability and, consequently, LTC has traditionally depicted a linear path from pathologies to impairment to the need for assistance, with focus on physical impairment (23). Despite being ignored, mental health-particularly dementia-is relevant today because it is identified as the leading cause of dependency in older people (24), and its prevalence is expected to increase, particularly in the Region (25). It is important to consider this group from the beginning, as well as other groups that are traditionally excluded (such as children). This avoids going through future processes of change, since recent experiences have shown these can be long and complex $(26,27)$.

Measurement issues: generating regular information. Dependency measurement entails several definitions $(19,22)$. First, it is necessary to define what will be considered as an ADL. These can include basic, instrumental, and advanced activities of daily living. The measure needs to decide whether to use one or more of these activities and how to combine them to classify a person as "dependent." Second, a specific instrument to measure limitations and/or help required for ADL has to be selected. Dependency could be measured using standardized or ad hoc instruments, adaptation of existing ones, or other methods (e.g., medical examination). Finally, the measurement should also consider the expected time and effort required to provide this help. This is an important issue, as it recognizes not only the need to evaluate difficulties to perform ADL but also their "long-term" condition; prevalence and services can vary enormously when considering different expected periods for the loss of functional ability (28). Assessing the type and expected length of care needed is a task in which the health sector plays an important role.

Once decided on definitions and measurements, countries should generate information on LTC needs and dependency prevalence. Depending on each country, this process can be carried out at different levels. Countries could start by collecting and systematizing information from studies or implementing a pilot to test instruments and validate definitions. These data will allow countries to assess the scale of the problem and design policies to address it.

It is important to develop a strategy for collecting and updating national-level LTC statistics, particularly considering the speed at which LTC needs are expected to increase. Increasing the frequency of the data is not simple but can be done by including LTC identification questions in surveys that are already being carried out, as done by Chile (29), or by building LTC-specific information systems, as in Uruguay (30).

\section{Thinking about solutions (policy stream)}

Along with defining and measuring the problem, countries in the Region need to break the chain of inaction by putting in place a gradual scaling-up of initiatives to advance with solutions that will be implemented in a well-timed period. This sense of urgency calls for immediate action, which does not imply implementing the chosen solution in a short span of time.

LTC systems are complex, and this complexity can explain countries' reluctance to implement them $(21,22)$. Although countries should start thinking about LTC now, any proposal promoting the adoption of LTC systems needs to consider some degree of gradualism; this is even more important when thinking about the regional level, as suggestions should also consider the heterogeneity of the countries. There are two initiatives that countries should embark on to respond to the increase in LTC needs in the Region: identifying LTC-related initiatives in place, and starting the design and implementation of LTC systems.

It's not starting from scratch! Current programs and policies. Countries can start today by listing what they are already doing in terms of LTC. This is an important two-fold short-run strategy: it helps build a future LTC system but also shows that countries, regardless of their current situation, are not starting from zero.

Finding LTC-related initiatives can be challenging at first, as concepts like "long-term care" and "dependency" are not always present. However, it is relatively simple to identify LTC-related initiatives, usually labeled as "elderly" or "disability" programs.

Being aware of the existence of these initiatives is important because it avoids overwhelming feelings when thinking about an LTC system. Showing that the country is already doing something to tackle LTC needs means that implementing a system is less costly than what is frequently thought. Of course, building an LTC system will require adapting and scaling-up initiatives and programs and, consequently, devoting extra resources. However, it is important for countries to acknowledge that they are already providing LTC services (although they call them differently). Implementing an LTC system is an efficient way to coordinate these efforts.

Toward an LTC system. In the long run, the Region should move toward implementing LTC systems, following the call of the World Health Organization to develop LTC systems in every country (31), adapting them to their needs and goals, to provide responses in a way that is effective (gives an answer to the population needs), sustainable (can be implemented with the available resources), and coherent (takes into account the interactions between its components). The system's design should consider its potential as a tool to address other issues related to LTC, such as inequities in different aspects (gender, income, and geographical access).

This task requires good information on the country's LTC demand and supply for LTC services, to define the LTC system's "building blocks." As previously described, identifying people with LTC needs is a key element of the system; the LTC system also needs definitions in terms of other components, such as benefits, providers, and financing (22). This relates to the previous points on the need for collecting and identifying LTC initiatives in place. The gap between these factors gives a measure of the space of intervention in terms of LTC coverage: number of people needing and receiving LTC services (width), number of services offered and required (depth), and costs of services (height) (32). 


\section{Building support and consensus (politics stream)}

Action toward LTC systems needs political will and population-based support. People and decisionmakers have to see this issue as an important one that requires urgent action. Building consensus about the necessity to implement LTC systems also requires time and resources. As mentioned before, short- and long-run strategies are necessary.

Broadening the audience: economic impact. Although there are many good arguments for the implementation of LTC systems, the economic impact is relevant because governments are constantly reluctant to implement initiatives that require extra resources and are looking for cost-containment strategies (20, 21). Consequently, in the short run, countries need to generate information on the economic impact of not having an LTC system to convene people and policymakers. This process can also be divided into smaller processes that can be carried out at different paces by different countries. A first stage for countries with no information about their situation could be to look at the experience of other countries already embarked on the process of developing LTC systems. This can be useful to look for alternatives and understand the decision-making and the arguments used to justify the need for action. Although countries can differ, this can be useful for projecting needs and prospecting solutions.

Second, countries should also start collecting information on the economic impact of LTC on their economies and people. This can include the economic value of caregiving, the impact of LTC on labor markets and investments, or the efficiency of social security (20). This information can be collected by systematizing national-level information or by producing and analyzing small-scale studies.

Looking at the future: LTC systems in every country. In the long run, countries should invest in formalizing their LTC systems. This process requires convincing policymakers and stakeholders to implement LTC policies and programs and moving toward the implementation of an LTC system. Many countries have included LTC as part of their social security apparatus. This represents a change in paradigm from a reactive model to one that anticipates future needs and proposes comprehensive responses.

New programs, laws, and policies should be implemented; once a country already has LTC-related information and benefits in place, the rationale for implementing an LTC system should become more and more evident. An LTC system can coordinate different actors and initiatives in an efficient way: increasing coverage, avoiding overlap between LTC-related initiatives, designing customized solutions for specific problems, and promoting a continuum of care, including different services (prevention, support services, and rehabilitation) and settings (home-based, health care, and institutionalized care) (20). This is relevant because it improves the efficiency of the social security system but also reduces uncertainty for families facing the problem.

Finally, countries should also explicitly consider the system's governance and develop a monitoring and evaluation (M\&E) system attached to the LTC system. This would permit assessing the system's performance, transforming it from an information-consuming into an information-generating
TABLE 1. Summary of strategies to deal with long-term care challenges in the Americas

\begin{tabular}{lcc}
\multicolumn{1}{c}{ Goal } & Short term & Long term \\
$\begin{array}{l}\text { Defining and } \\
\text { measuring LTC } \\
\text { needs }\end{array}$ & $\begin{array}{c}\text { Adopting/reviewing a } \\
\text { national definition }\end{array}$ & $\begin{array}{c}\text { Assessing the } \\
\text { relevance of the } \\
\text { definition (updating }\end{array}$ \\
& $\begin{array}{c}\text { Systematizing } \\
\text { information on } \\
\text { dependency and }\end{array}$ & $\begin{array}{c}\text { National surveys/ } \\
\text { studies to measure }\end{array}$ \\
& caregiving & LTC needs \\
& Small-scale studies & Administrative \\
& & records \\
Implementing & Inventory of current & Designing an LTC \\
responses to LTC & initiatives & system \\
needs & & Implementing an LTC system \\
& & system \\
Building support & Looking at & Advocacy with \\
and consensus & international & policymakers \\
& experiences & and society \\
& Systematizing & stakeholders \\
& information on & \\
& dependency & \\
& and caregiving, & \\
& including economic & \\
& aspects & \\
& Small-scale studies & \\
\hline
\end{tabular}

LTC, long-term care; M\&E, monitoring and evaluation.

Source: Prepared by the authors.

system: an M\&E system can generate updated information on LTC needs in the country (understanding the problem), what works and why in terms of LTC services (thinking about solutions), and the costs and savings that an LTC system generates for the country (building consensus) (Table 1).

The proposed strategy stresses the countries' need for implementing LTC initiatives at national level but also builds on a novel focus-adopting a regional common strategy-to approach LTC. This poses a challenge for regional organizations to foster the debate and coordinate regional efforts. Addressing LTC from a regional approach can enhance learning processes and contribute to tackling some of the actual issues, such as data comparability, measurement, service provision, and financing.

\section{CONCLUSIONS}

This article highlights the challenges faced by the Region and the importance of building LTC systems to address them. The response of the countries to this challenge has been scarce due to issues in identifying the problem, designing and implementing solutions, and generating consensus on the need for action.

In this context, the article presents a strategy for the Region, to encourage the implementation of LTC systems as a response for the coming challenges. It is necessary to take into account the heterogeneity between countries when thinking of a regional strategy. However, even when considering the different contexts in the Region, the sense of urgency remains. LTC is not an issue that only concerns "old" countries: as implementing solutions takes time, "young" countries also need to start preparing their response to the increase in LTC needs. Convincing policymakers and the public that LTC is an urgent matter will foster the adoption of initiatives to tackle this problem. 
LTC is not a "rich-countries' problem." Eventually, every country will face it. Likewise, LTC systems are not "rich countries' solutions." LTC systems can be adapted to the countries' needs, resources, and priorities. Therefore, the article suggests short-term and long-term strategies to move forward in the debate and turn it into actionable proposals, considering each country's reality.

Finally, a deeper debate on the role of the health sector is needed. When talking about LTC, a common remark is that LTC has nothing to do with health. We show exactly the opposite.

First, despite the usual narrative about LTC being a social issue, LTC needs are originated by a loss in functional ability, linked to health issues. Consequently, the health sector is essential in determining and classifying these needs. Second, the debate on LTC minimizes the role of the health sector in providing LTC services, traditionally understood as social services. On the contrary, the health sector plays a crucial role, not only in complementing social services provided to people with LTC needs but also in decreasing the demand for LTC services in the population; the health sector fulfills an important role through the implementation of prevention and rehabilitation strategies. Finally, in terms of creating awareness about the need to take action, the health sector is important to show how LTC can be seen not only as an extra expenditure but also as a strategy for cost containment. Several LTC-related expenditures are today being taken over by the health system-like patients using hospital beds for non-clinical reasons and who cannot be discharged because they lack a relative to take care of them-and health care for dependents and caregivers. An LTC system can help in reducing these costs by providing cost-efficient solutions to specific problems.

In summary, this article shows that LTC is an important issue for all countries in the Region today and will continue to grow at a quick pace in the coming years. Regional stakeholders should take further steps to organize the discussion on LTC, coordinating efforts and helping to harmonize national and regional decision-making. On the other hand, countries need to start thinking about this challenge and preparing their health and social security systems for these changes. The article proposes three dimensionsunderstanding the problem, thinking about solutions, and building support and consensus-to translate this concern into action; the three elements are required to advance toward the implementation of comprehensive and sustainable responses to the challenges of LTC. The main message is that addressing these changes is urgent and complex, but also possible. Countries should start implementing initiatives to build their LTC systems today.

Author contributions. All authors conceived the original idea. PVD wrote the first draft. All authors contributed to the analysis and the writing of the final manuscript. All authors reviewed and approved the final version.

Acknowledgments. The authors are thankful for the comments received from three anonymous reviewers and the Journal's editor. Their suggestions helped improve the original manuscript.

Conflict of interest. $\mathrm{CH}$ and EV were employed by the Pan American Health Organization (PAHO) at the time the manuscript was written and submitted. All other authors declare no conflict of interest.

Disclaimer. Authors hold sole responsibility for the views expressed in the manuscript, which may not necessarily reflect the opinion or policy of the RPSP/PAJPH and/or PAHO.

\section{REFERENCES}

1. United Nations, Department of Economic and Social Affairs [Internet]. New York: United Nations; 2019 [accessed 2020 Sep 8]. World Population Prospects 2019. Available from: https://population. un.org/wpp/.

2. Institute for Health Metrics and Evaluation [Internet]. Seattle: University of Washington; 2017 [accessed 2020 Sep 8]. GBD Compare Viz Hub. Available from: https://vizhub.healthdata.org/ gbd-compare/.

3. Colombo F, Llena-Nozal A, Mercier J, Tjadens F. Help Wanted. Providing and Paying for Long-Term Care. Paris: OECD Publishing; 2011.

4. Gómez Dantés O, García Peña MC, Sánchez García S, Rosas Carrasco O, Campuzano Rincón JC, Lozano R. Escenarios de la dependencia en México. In: Gutiérrez Robledo LMF, García Peña MC, Jiménez Bolón JE (eds.). Envejecimiento y dependencia: Realidades y previsión para los próximos años. Mexico City: Academia Nacional de Medicina; 2014.

5. World Health Organization [Internet]. Geneva: WHO; 2020 [accessed 2021 Mar 12]. Decade of Healthy Ageing 2020-2030. Available from: https://www.who.int/docs/default-source/decade-of-healthyageing/final-decade-proposal/decade-proposal-final-apr2020-en. pdf

6. Cafagna G, Aranco N, Ibarrarán P, Medellín N, Oliveri ML, Stampini M. Age with Care: Long-Term Care in Latin America and the Caribbean; Washington, DC: Inter-American Development Bank; 2019. Available from: https://publications.iadb.org/en/age-carelong-term-care-latin-america-and-caribbean Accessed 2021 Mar 12.
7. Kingdon JW. Agendas, Alternatives, and Public Policies. 2nd edition. Boston, MA: Pearson; 1995.

8. Villalobos Dintrans P. Is aging a problem? Dependency, longterm care, and public policies. Rev Panam Salud Pública. 2018; 42:e168.

9. Scheil-Adlung X. Long-term care protection for older persons: a review of coverage deficits in 46 countries. ESS Working Paper 50. Geneva: International Labour Office; 2015.

10. Organisation for Economic Co-operation and Development; European Commission. A Good Life in Old Age? Monitoring and Improving Quality in Long-Term Care. Paris: OECD Publishing; 2013.

11. World Health Organization. World Report on Ageing and Health. Geneva: WHO; 2015.

12. National Institute on Aging [Internet]. Bethesda, MD: NIA; 2017 [accessed 2020 Aug 12]. What is Long-Term Care? Available from: https://www.nia.nih.gov/health/what-long-term-care

13. Villalobos Dintrans P. Long-term care in Chile: the faces of dependency. ReVista, Harvard Review of Latin America. Winter 2019. 2019 Dec 7;18(9).

14. Aranco N, Stampini M, Ibarrarán P, Medellín N. Panorama de envejecimiento y dependencia en América Latina y el Caribe. Resumen de Políticas $\mathrm{N}^{\circ}$ IDB-PB-273. Washington, DC: Banco Interamericano de Desarrollo; 2018.

15. Servicio Nacional del Adulto Mayor. Estudio Nacional de la Dependencia en Adultos Mayores. Santiago (Chile): Servicio Nacional del Adulto Mayor; 2010. Available from: http://www.senama.cl/ 
filesapp/Estudio $\% 20$ Nacional\%20de \%20Dependencia $\% 20$ en $\% 20$ las\%20Personas\%20Mayores.pdf Accessed 2020 Aug 16.

16. López Ortega M, Jiménez Bolón JE. Dependencia y cuidados de largo plazo. In: Gutiérrez Robledo LMF, García Peña MC, Jiménez Bolón JE (eds.). Envejecimiento y dependencia: Realidades y previsión para los próximos años. Mexico City: Academia Nacional de Medicina; 2014.

17. Sistema de Cuidados. Construcción de Baremos para Valoración de Dependencia. Montevideo: Sistema de Cuidados; 2015. Available from: http://www.mides.gub.uy/innovaportal/file/99818/1/ construccion-de-baremos-para-valoracion-de-dependencia.pdf Accessed 2020 Aug 16.

18. Agencia Nacional de Discapacidad. Instrumento para evaluación de dependencia. Buenos Aires: Agencia Nacional de Discapacidad; 2019.

19. Villalobos Dintrans P, González Bautista E. Functional Dependency in Mexico: Measurement Issues and Policy Challenges. Int J Health Policy Manag. 2020; online ahead of print. doi: 10.34172/ ijhpm.2020.248

20. Villalobos Dintrans P. Long-term care systems as social security: the case of Chile. Health Policy Plan. 2018;33(9):1018-25.

21. Brodsky J, Clarfield AM. Long Term Care in Health Services. In: Heggenhougen HK, Quah S (eds.). International Encyclopedia of Public Health. San Diego, CA: Academic Press; 2008.

22. Villalobos Dintrans P. Designing long-term care systems: Elements to consider. J Aging Soc Policy 2020;32(1):83-99. doi: 10.1080/08959420.2019.1685356

23. Nagi SZ. Some conceptual issues in disability and rehabilitation. In: Sussman MB (ed.). Sociology and Rehabilitation. Washington, DC: American Sociological Association; 1965.

24. Sousa RM, Ferri CP, Acosta D, Albanese E, Guerra M, Huang Y, et al. Contribution of chronic diseases to disability in elderly people in countries with low and middle incomes: a 10/66 Dementia Research Group population-based survey. Lancet. 2009;374(9704):1821-30.
25. World Health Organization. Dementia: a public health priority. Geneva: WHO; 2012.

26. Federal Ministry of Health. Report by the Advisory Board to Review the Definition of the Need for Long-Term Care. Bonn: Federal Ministry of Health; 2009. Available from: https://www.bundesge sundheitsministerium.de/fileadmin/Dateien/3_Downloads/E/ Englische_Dateien/Report_by_the_advisory_board_to_review_ the_definition_of_the_need_for_long-term_care.pdf Accessed 2020 Aug 24.

27. Jeon B, Kwon S. Health and Long-Term Care Systems for Older People in the Republic of Korea: Policy Challenges and Lessons. Health Syst Reform. 2017;3(3):214-23.

28. Stallard E. Long Term Care for Aging Populations. In: Heggenhougen HK, Quah S (eds.). International Encyclopedia of Public Health. San Diego, CA: Academic Press; 2008.

29. Villalobos Dintrans P. Panorama de la dependencia en Chile: Avances y desafíos. Rev Med Chile. 2019;147(1):83-90.

30. Junta Nacional de Cuidados. Plan Nacional de Cuidados 2016-2020. Montevideo: Junta Nacional de Cuidados; 2015. Available from: https://www.gub.uy/sistema-cuidados/institucional/plan-estra tegico/plan-nacional-cuidados-2016-2020 Accessed 2020 Aug 28.

31. World Health Organization. Global Strategy and Action Plan on Ageing and Health: A Framework for Coordinated Global Action by the World Health Organization, Member States, and Partners across the Sustainable Development Goals. Geneva: WHO; 2016.

32. World Health Organization. World Health Report 2010: Health Systems Financing: The Path to Universal Coverage. Geneva: WHO; 2010.

Manuscript received on 10 November 2020. Revised version accepted for publication on 29 March 2021. 


\section{Establecimiento de sistemas de cuidados a largo plazo en la Región de las Américas: una estrategia regional}

RESUMEN La Región de las Américas está haciendo frente a acelerados cambios demográficos y epidemiológicos. Considerando que estas tendencias se mantendrán en los años venideros, se prevé que la necesidad de cuidados a largo plazo se incrementará. ¿Cómo pueden responder los países a estos retos?

Proponemos que los países de la Región inviertan en el establecimiento de sistemas de cuidados a largo plazo. Considerando la heterogeneidad de la Región, proponemos una estrategia fundamentada en tres componentes: a) comprender el problema; b) pensar en soluciones; y c) generar apoyo y consenso. De acuerdo con las necesidades y las capacidades de cada país, estos tres elementos determinan los objetivos y las medidas a corto y largo plazo, desde la producción de mejor información sobre las necesidades de cuidados a largo plazo hasta el establecimiento de sistemas de cuidados a largo plazo.

Hoy en día, los cuidados a largo plazo son una cuestión pertinente en la Región. Aunque esta tarea represente un reto, los países deben aceptarlo y progresar antes de que sea demasiado tarde.

Palabras clave Cuidados a largo plazo; política de salud; sistemas de salud; seguridad social; planificación en salud; Américas.

\section{Implementação de sistemas de assistência a longo prazo nas Américas: uma estratégia regional}

RESUMO A Região das Américas encontra-se em transição demográfica e epidemiológica acelerada. Esta tendência deve persistir nos próximos anos e antecipa-se um crescimento da demanda por assistência a longo prazo. Como os países podem enfrentar estes desafios?

A nossa proposta é que os países das Américas invistam na implementação de sistemas de assistência a longo prazo. Como a Região se caracteriza pela heterogeneidade entre os países, propomos uma estratégia alicerçada em três componentes: (i) entender o problema, (ii) buscar soluções e (iii) granjear apoio e consenso. Dependendo das necessidades e da capacidade de cada país, esses três componentes devem servir para estabelecer metas e ações a curto ou longo prazo, que vão desde aprofundar o conhecimento sobre as necessidades existentes a implementar os sistemas em si. A assistência a longo prazo é uma questão atual de interesse para a Região. A tarefa envolve muitos desafios, mas os países precisam encampá-la e avançar antes que seja tarde demais.

Palavras-chave Assistência de longa duração; política de saúde; sistemas de saúde; previdência social; planejamento em saúde; América. 